primer. A sequence change from $\mathrm{T}$ to $\mathrm{G}$ at nucleotide position 1,908 occurred in CAST/Ei relative to inbred strains, such as DBA/2J, C3HeB/FeJ, C57BL/6J, and $\mathrm{BALB} / \mathrm{cByJ}$ (data not shown); however, this polymorphism does not change the coding of this alanine residue and could account for the non- $L c$-specific difference seen in Fig. 2a. At nucleotide position 1,960, all sequences consistently show single peaks of $\mathrm{A}$ in all $L c$ and $L c^{J}$ homozygous samples, or double peaks of $\mathrm{G}$ and $\mathrm{A}$ in all $L c$ and $L c^{J}$ heterozygous samples.

Electrophysiology in cerebellar Purkinje cells. Slices $(200 \mu \mathrm{m}$ thick) of cerebellar vermis were prepared from $L c /+$ and $L c^{J} /+$ mice (10 and 11 days old) and their wild-type littermates. Purkinje cells were whole-cell patch-clamped at a command potential of $-70 \mathrm{mV}$ using standard methods. External saline consisted of (in mM): $127 \mathrm{NaCl}, 2.5 \mathrm{KCl}, 2 \mathrm{CaCl}_{2}, 1 \mathrm{MgCl}_{2}, 1 \mathrm{NaH}_{2} \mathrm{PO}_{4}, 26.3$ $\mathrm{NaHCO}_{3}, 20$ glucose, 0.02 bicuculline, 0.005 tetrodotoxin, $\mathrm{pH} \sim 7.35$, $320 \mathrm{mmol} \mathrm{kg}^{-1}$. For NMDG-substituted external saline, all $\mathrm{NaCl}$ in the above formulation was replaced with $138 \mathrm{mM}$ NMDG and the $\mathrm{pH}$ was adjusted with $\mathrm{HCl}$, reducing external $\mathrm{Na}^{+}$concentration to $27.3 \mathrm{mM}$ (thereby changing $E_{\mathrm{Na}}$ from about $+67.4 \mathrm{mV}$ to $+23.2 \mathrm{mV}$ ). Internal solution of (in $\mathrm{mM}$ ): $15 \mathrm{KCl}, 135$ potassium gluconate, $1 \mathrm{MgCl}_{2}, 10 \mathrm{HEPES}, 4 \mathrm{Na}_{2} \mathrm{ATP}, 1 \mathrm{Na}_{3} \mathrm{GTP}, 10$ sucrose, $\mathrm{pH}$ $\sim 7.25,300 \mathrm{mmol} \mathrm{kg}^{-1}$. Series and input resistances were derived from membrane current responses to 125 -ms voltage steps to $-75 \mathrm{mV}$.

Fewer Purkinje cells were visible in $L c /+$ than in wild-type cerebellar slices, and those that were present appeared shrivelled and granular. In mutant slices, those Purkinje cells that appeared most healthy were chosen for electrophysiological analysis. The two alleles, $L c /+$ and $L d /+$, were indistinguishable in electrophysiological recordings and results were combined. $L c /+$ recordings segregated into two groups based on their final holding currents following NMDG substitution. In most $L c /+$ Purkinje cells (Fig. 3 b, filled circles, $n=7$ ), post-NMDG holding currents were very small. In a few $L c /+$ cells however, the final holding currents in the presence of NMDG were very large despite the decrease observed in response to this substitution (Fig. 3b, open circles, $n=2$ ). This large residual holding current was probably a sign of compromised recording integrity, evidence of which had initially been masked by the $L c /+$ constitutive current. Thus data from these cells were excluded from the mean calculations of both basic $L c /+$ membrane properties (holding current and conductance; Fig. 3a) and changes in these values produced by NMDG substitution (Fig. 3c) to avoid artefactually increasing the $L c /+$ effect. The values we report here, therefore, were derived only from those $L c /+$ cells for which the post-NMDG holding currents were more positive than $-230 \mathrm{pA}$.

Electrophysiology in Xenopus oocytes. Two oligonucleotides were designed with homology to the $5^{\prime}$ and $3^{\prime}$ ends of the mouse GluR $\delta 2$ cDNA coding sequence. The $L c$ mutation was generated using the bridge PCR mutagenesis method $^{22}$. The $L c$ mutation in mutant clones was verified by sequencing. In vitro translation was used to confirm that both wild-type and mutant constructs yielded the expected products of $M_{\mathrm{r}} \sim 110 \mathrm{~K}$ in an SDS-PAGE gel. Concentrations of cRNAs were measured by gel electrophoresis and spectrophotometer. Approximately $65-85 \mathrm{ng}$ per $50 \mathrm{nl}$ of the cRNAs were injected into stage V or VI oocytes from Xenopus laevis (Nasco and Xenopus Express). Electrophysiological recordings were performed 1-3 days postinjection using the two-microelectrode voltage-clamp configuration at room temperature ${ }^{23}$. The recording-bath chamber was $\sim 150 \mu \mathrm{l}$ in volume and the flow rate $2-$ $3 \mathrm{ml} \mathrm{min}^{-1}$. Most recordings were made in a $\mathrm{Na} / \mathrm{Ca}$ solution containing (in $\mathrm{mM}): 130 \mathrm{NaCl}, 2 \mathrm{CaCl}_{2}$ and 10 HEPES, pH 7.3. For NMDG substitution experiments, an equimolar substitution of NMDG for $\mathrm{NaCl}$ was made ( $\mathrm{pH} 7.3$, adjusted with $\mathrm{HCl}$ ). Fresh stock solutions were made in the $\mathrm{Na} / \mathrm{Ca}$ recording solution and kept on ice: L-glutamate (100 mM, Sigma), L-aspartate $(100 \mathrm{mM}$, Sigma), glycine (100 mM, Sigma), kainic acid ( $1 \mathrm{mM}$, Research Biochemicals), CNQX (1 mM, Research Biochemicals, AP5 (1 mM, Research Biochemicals), 7chlorokynurenic acid (10 mM, Research Biochemicals). For resting-potential measurements, close readings between two microelectrodes (less than $5 \mathrm{mV}$ difference) were indicating of good seals of the microelectrodes to the oocyte membrane. When NMDG bath was perfused after $\mathrm{Na}^{+}$bath, the readings of two microelectrodes moved very closely to more hyperpolarized or negative directions until they reached a relatively stable state, between -50 and $-90 \mathrm{mV}$. Some oocytes did not reach such a hyperpolarized state with NMDG, either before or after changes of external baths for measurements, usually indicating compromised membrane integrity, so these oocytes were not further studied. For current-voltage relationships, oocytes were held at their resting potentials and stimulated with voltage steps of $50 \mathrm{~ms}$ and $10 \mathrm{mV}$ from -140 to $+100 \mathrm{mV}$, each pulse being separated by $2 \mathrm{~s}$. Currents were measured after 25 -ms during each pulse. Conductance was derived from the difference between the holding currents at -50 and at $-60 \mathrm{mV}$.

Received 10 March; accepted 2 June 1997.

1. Phillips, R. J. S. "Lurcher", new gene in linkage group XI of the house mouse. J. Genet. 57, 35-42 (1960).

2. Caddy, K. W. \& Biscoe, T. J. Structural and quantitative studies on the normal $\mathrm{C} 3 \mathrm{H}$ and Lurcher mutant mouse. Phil. Trans. R. Soc. Lond. B 287, 167-201 (1979).

3. Wetts, R. \& Herrup, K. Interaction of granule, Purkinje and inferior olivary neurons in Lurcher chimaeric mice. I. Qualitative studies. J. Embryol. Exp. Morphol. 68, 87-98 (1982).

4. Normal, D. J. et al. The Lurcher gene induces apoptotic death in cerebellar Purkinje cells. Development 121, 1183-1193 (1995).

5. Cheng, S. S. \& Heintz, N. Massive loss of mid- and hindbrain neurons during embryonic development of homozygous Lurcher mice. J. Neurosci. 17, 2400-2407 (1997).

6. Hollmann, M. \& Heinemann, S. Cloned glutamate receptors. Annu. Rev. Neurosci. 17, 31-108 (1994).

7. Lomeli, H. et al. The rat delta- 1 and delta-2 subunits extend the excitatory amino acid receptor family. FEBS Lett. 315, 318-322 (1993).

8. Araki, K. et al. Selective expression of the glutamate receptor channel $\delta 2$ subunit in cerebellar Purkinje cells. Biochem. Biophys. Res. Commun. 197, 1267-1276 (1993).

9. Kashiwabuchi, N. et al. Impairment of motor coordination, Purkinje cell synapse formation, and cerebellar long-term depression in GluR $\delta 2$ mutant mice. Cell 81, 245-252 (1995).

10. Zuo, J., De Jager, P. L., Norman, D. J. \& Heintz, N. Generation of a high-resolution genetic map and a YAC contig of the Lurcher locus on mouse chromosome 6. Genome Res. 5, 381-392 (1995).

11. De Jager, P. L., Zuo, J. \& Heintz, N. An $\sim 1.2 \mathrm{Mb}$ BAC contig refines the genetic and physical maps of the Lurcher locus on mouse chromosome 6. Genome Res. 7, 736-746 (1997).

12. De Jager, P. L., Zuo, J., Cook, S. A. \& Heintz, N. A new ataxic mouse mutant, NM1991, is new allele of the Lurcher gene, $L c$. Mamm. Genome (in the press).

13. Takayama, C., Nakagawa, S, Watanabe, M., Mishina, M. \& Inoue, Y. Developmental changes in expression and distribution of the glutamate receptor channel $\delta 2$ subunit according to the Purkinje cell maturation. Dev. Brain Res. 92, 147-155 (1996).

14. Mayat, E., Petralia, R. S., Wang, Y. \& Wenthold, R. J. Immunoprecipitation, immunoblotting, and immunocytochemistry studies suggest that glutamate receptor $\delta$ subunits form novel postsynaptic receptor complexes. J. Neurosci. 15, 2533-2546 (1995).

15. Takayama, C., Nakagawa, S., Watanabe, M., Mishina, M. \& Inoue, Y. Light- and electron-microscopic localization of the glutamate receptor channel $\delta 2$ subunit in the mouse Purkinje cell. Neurosci. Lett. 188, 89-92 (1995).

16. Landsend, A. S. et al. Differential localization of $\delta$ glutamate receptors in the rat cerebellum: coexpression with AMPA receptors in parallel fiber-spine synapses and absence from climbing fiber-spine synapses. J. Neurosci. 17, 834-842 (1997).

17. Choi, D. W. Calcium: still center-stage in hypoxic-ischemic neuronal death. Trends Neurosci. 18, $58-$ 60 (1995).

18. Patel, N. et al. A potassium channel mutation in weaver mice implicates membrane excitability in granule cell differentiation. Nature Genet. 11, 126-129 (1995).

19. Burgess, D. L. et al. Mutation of a new sodium channel gene, Scn8a, in the mouse mutant 'motor endplate disease'. Nature Genet. 10, 461-465 (1995).

20. Fletcher, C. F. et al. Absence epilepsy in tottering mutant mice is associated with calcium channel defects. Cell 87, 607-617 (1996).

21. Burgess, D. L., Jones, J. M., Meisler, M. H. \& Noebels, J. L. Mutation of the $\mathrm{Ca}^{2+}$ channel $\beta$ subunit gene Cchb4 is associated with ataxia and seizures in the Lethargic (lh) mouse. Cell 88, 385-392 (1997).

22. Ho, S. N., Hunt, H. D., Horton, R. M., Pullen, J. K. \& Pease, L. R. Site-directed mutagenesis by overlap extension using the polymerase chain reaction. Gene 77, 51-59 (1989).

23. Quick, M. W. \& Lester, H. A. Methods for expression of excitability proteins in Xenopus oocytes. Methods Neurosci. 19, 261-279 (1994).

Acknowledgements. We thank W. Hu for technical assistance; R. MacKinnon and J. Imredy for advice and help with oocyte physiology experiments; colleagues of the Heintz and Linden laboratories for discussion and support; and C. Desplan, R. Duvoisin, J. Friedman, A. Hirano, A. J. Hudspeth, A. S. Peterson, N. Segil and Z P. Sun for critical reading of the manuscript. J.Z., W.J. and N.H. are supported by HHMI; P.L.D. is supported by NIH/NIGMS; D.J.L. is supported by PHS MH51106, the McKnight Foundation, the Develbiss Fund, and the National Alliance for Research on Schizophrenia and Depression.

Correspondence and requests for materials should be addressed to N.H. (e-mail: heintz@rockvax. rockefeller.edu)

\section{A second endogenous cannabinoid that modulates long-term potentiation}

\section{Nephi Stella, Paul Schweitzer ${ }^{\star}$ \& Daniele Piomelli}

The Neurosciences Institute, San Diego, California 92121, USA

* Department of Neuropharmacology, The Scripps Research Institute, La Jolla, California 92037, USA

Cannabinoid receptors are molecular targets for marijuana and hashish, the widespread drugs of abuse. These receptors are expressed in areas of the central nervous system that contribute in important ways to the control of memory, cognition, movement and pain perception ${ }^{1}$. Indeed, such functions can be strongly influenced by cannabinoid drugs, with consequences that include 
euphoria, analgesia, sedation and memory impairment ${ }^{2}$. Although the pharmacology of cannabinoid drugs is now beginning to be understood, we still lack essential information on the endogenous signalling system(s) by which cannabinoid receptors are normally engaged. An endogenous ligand for cannabinoid receptors, anandamide, has been described ${ }^{3}$. Here we report that $s n-2$ arachidonylglycerol (2-AG), a cannabinoid ligand isolated from intestinal tissue ${ }^{4}$, is present in brain in amounts 170 times greater than anandamide. $2-\mathrm{AG}$ is produced in hippocampal slices by stimulation of the Schaffer collaterals, an excitatory fibre tract that projects from CA3 to CA1 neurons. Formation of 2-AG is calcium dependent and is mediated by the enzymes phospholipase $C$ and diacylglycerol lipase. 2-AG activates neuronal cannabinoid receptors as a full agonist, and prevents the induction of long-term potentiation at CA3-CA1 synapses. Our results indicate that $2-\mathrm{AG}$ is a second endogenous cannabinoid ligand in the central nervous system.
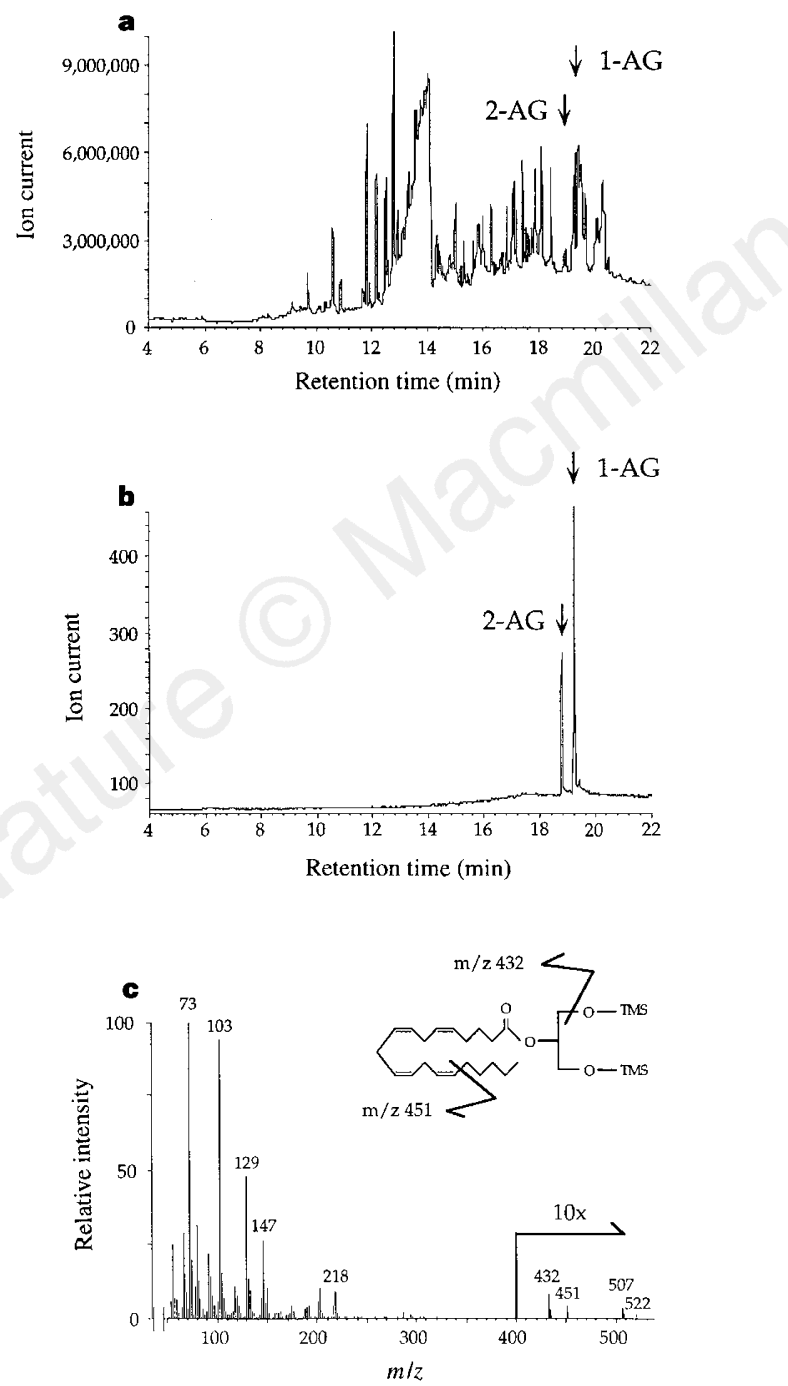

Figure 1 Identification of 2-arachidonylglycerol (2-AG) in rat brain by GC/MS. Monoacylglycerols were purified chromatographically and analysed by GC/MS as bis trimethylsilylether (TMS) derivatives. a, Total ion current chromatogram of HPLC-purified material from one brain. Arrows indicate the retention times of synthetic 2-AG and 1(3)-AG. b. Selected-ion monitoring (SIM) analysis. c, Electronimpact mass spectrum of 2-AG purified from brain, which was identical to that of synthetic 2-AG (data not shown). Results are from one experiment, representative of four.
Anandamide fulfils several criteria of an endogenous cannabinoid substance: (1) it is present in brain and activates cannabinoid receptors $^{3}$; (2) it is released from depolarized neurons $s^{5,6}$; and (3) it undergoes rapid biological inactivation ${ }^{5,7-10}$. Nevertheless, the exceedingly low levels of anandamide in brain ${ }^{11-14}$ and the discrepancies observed between its pharmacological properties and those of other cannabinoid drugs ${ }^{15}$ indicate that additional cannabinoids may exist. In support of this possibility, cannabinoid receptor ligands that are chemically distinct from anandamide have been found in tissues ${ }^{4,16}$. One such ligand was isolated from dog intestine and characterized as $s n-2$ arachidonylglycerol (2-AG) ${ }^{4}$. 2-AG binds to cannabinoid receptors and exerts several effects typical of cannabinoid drugs ${ }^{4,17}$. Yet the possible role of $2-A G$ as an endogenous cannabinoid remains unknown; even its occurrence in brain is at present controversial ${ }^{4,17}$.

To determine whether 2-AG is present in brain, we analysed lipid extracts of rapidly frozen rat brains using gas chromatography/mass spectrometry (GC/MS). A component was eluted from the GC at the retention time of 2-AG (analysed as bis trimethylsilylether derivative; Fig. 1a, b, $n=4$ ). We identified this component from its electron-impact mass spectrum (Fig. 1c). Diagnostic fragments included $m / z 522\left([\mathrm{M}]^{+}\right.$, molecular ion), $507\left([\mathrm{M}-15]^{+}\right.$, loss of methyl radical $), 451\left([\mathrm{M}-71]^{+}\right.$, loss of pentyl radical $)$, and $432[(\mathrm{M}-$ $90]^{+}$, loss of trimethylsilenol). Such fragmentation is typical of $s n-2$ acylglycerols, and identical to that of synthetic 2-AG (data not shown). The identification of $2-\mathrm{AG}$ was further supported by $\mathrm{GC} /$
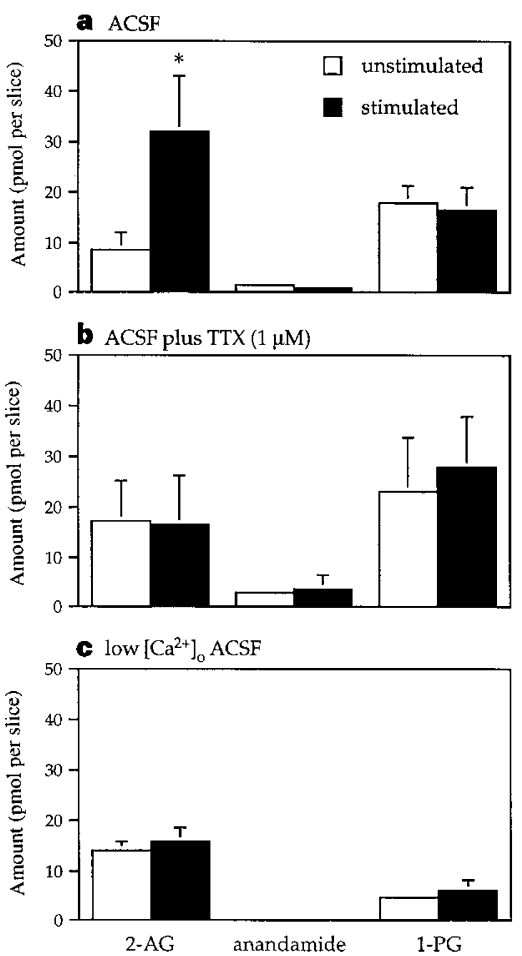

Figure 2 Neural activity stimulates 2-AG production in hippocampal slices. Effects of high-frequency stimulation (HFS) on the production of 2-AG, anandamide and 1(3)-palmitylglycerol (1-PG) in: a, artificial cerebrospinal fluid (ACSF); b, ACSF containing tetrodotoxin (TTX; $1 \mu \mathrm{M})$; c, ACSF with zero $\mathrm{Ca}^{2+}$ and $6 \mathrm{mM} \mathrm{Mg}^{2+}$. Unstimulated slices (white bars) and stimulated slices (black bars) were immersed in cold methanol after the experiment and lipids were extracted with chloroform. Acylglycerols and anandamide were purified by HPLC and analysed by GC/MS in the SIM mode as bis TMS derivatives. Average weight of the slices was $30.9 \pm 1.3 \mathrm{mg}, n=20$. Results represent the mean \pm s.e.m. of 3-7 experiments, each done on 4 slices. ${ }^{\star}, P<0.05$ significantly different from unstimulated controls (Wilcoxon non-parametric test). 
MS analysis of the bis trifluoroacetate derivative, which yielded the following diagnostic fragments: $[\mathrm{M}-43]^{+}$, loss of propyl radical; $[\mathrm{M}-71]^{+}$, loss of pentyl radical; $[\mathrm{M}-98]^{+}$, loss of trifluoroacetate. By comparison with an internal standard, we estimate that $2.4 \pm 1.3 \mathrm{nmol}$ of $2-\mathrm{AG}$ were recovered per $\mathrm{g}$ of brain tissue (mean \pm s.e.m.; $n=3$ ).

Figure $1 \mathrm{~b}$ also shows another GC component, which we identified as 1(3)-AG from its retention time and mass spectrum (data not shown). Although we recovered a substantial amount of 1(3)-AG $\left(1.6 \pm 0.6 \mathrm{nmolg}^{-1}, 40 \%\right.$ of total AG, $\left.n=3\right)$, this could be entirely accounted for by non-enzymatic isomerization of 2-AG. Indeed, when we subjected synthetic $2-A G$ to sample preparation, we found that $43.3 \pm 5.6 \%$ was isomerized to $1(3)-A G(n=6)$. Considering this reaction, we estimate that the content of 2-AG in brain is $4.0 \pm 1.8 \mathrm{nmol} \mathrm{g}^{-1}$. We made a similar correction in all subsequent measurements.

Because we used brains frozen within $10 \mathrm{~s}$ of decapitation, the levels of 2-AG obtained in our experiments are unlikely to reflect postischaemic lipid breakdown ${ }^{18}$. This conclusion was confirmed by measuring anandamide, which is sensitive to ischaemic challenge ${ }^{12}$. We measured $23 \pm 3$ pmol of anandamide per g of brain, a value that tallies well with those previously reported ${ }^{11-14}$. These analyses demonstrate that 2-AG is a prominent constituent of brain tissue, about 170 times more abundant than anandamide.

We determined whether neural activity affects $2-A G$ production by electrically stimulating superfused slices of hippocampus. Highfrequency stimulations (HFS) of the Schaffer collaterals, an excitatory CA1 afferent, elicited robust responses in CA1. Without stimulation, we measured $8.6 \pm 3.5 \mathrm{pmol}$ of $2-\mathrm{AG}$ per slice $(n=6)$. HFS produced a fourfold increase in 2-AG levels, to
$32.0 \pm 11.2 \mathrm{pmol}$ per slice (Fig. 2a). This effect was prevented by the $\mathrm{Na}^{+}$channel blocker tetrodotoxin $(1 \mu \mathrm{M})$ or by removal of $\mathrm{Ca}^{2+}$ ions, indicating that $2-\mathrm{AG}$ formation required both neuronal depolarization and external $\mathrm{Ca}^{2+}$ (Fig. 2b, c). Moreover, HFS was specific in stimulating 2-AG production, as the levels of 1(3)palmitylglycerol and 1(3)-stearylglycerol were not significantly changed (Fig. 2a-c and data not shown). In cultured neurons, anandamide formation is increased by membrane-depolarizing agents $^{5,6}$. However, HFS had no significant effect on anandamide levels in hippocampal slices. Anandamide was $1.5 \pm 0.7 \mathrm{pmol}$ per slice before, and $0.8 \pm 0.4$ pmol per slice after stimulation $(n=7$; Fig. 2a).

HFS increased 2-AG production only when $\mathrm{Ca}^{2+}$ was present in the superfusing medium. This suggests that $\mathrm{Ca}^{2+}$ stimulates enzyme activities involved in 2-AG production or that $\mathrm{Ca}^{2+}$ is required for the release of neurotransmitters that elicit 2-AG production. To address these possibilities, we studied 2-AG formation in serum-free cultures of rat brain neurons, which lack $\mathrm{Ca}^{2+}$-dependent neurotransmitter release ${ }^{19}$. We labelled the neurons with $\left[{ }^{14} \mathrm{C}\right]$ arachidonic acid (AA) and analysed the lipids by thin-layer chromatography (TLC). Figure $3 a$ shows that $\left[{ }^{14} \mathrm{C}\right] 2-\mathrm{AG}$ was accumulated in response to the $\mathrm{Ca}^{2+}$-ionophore ionomycin $(2 \mu \mathrm{M})$, and reduced by chelating external $\mathrm{Ca}^{2+}$ with EGTA $(1 \mathrm{mM})$. Thus, $\mathrm{Ca}^{2+}$ may act directly to increase 2-AG formation in neurons. We then determined whether astroglia may also contribute to 2-AG formation. Under basal conditions, cultures of brain astrocytes labelled with $\left[{ }^{14} \mathrm{C}\right] \mathrm{AA}$ contained only small amounts of $\left[{ }^{14} \mathrm{C}\right] 2-\mathrm{AG}$. $\left[{ }^{14} \mathrm{C}\right] 2-\mathrm{AG}$ was reduced below detection by EGTA, but was not affected by ionomycin even though the $\mathrm{Ca}^{2+}$ ionophore significantly increased the levels of non-esterified $\left[{ }^{14} \mathrm{C}\right] \mathrm{AA}$ (Fig. 3b). Thus, although
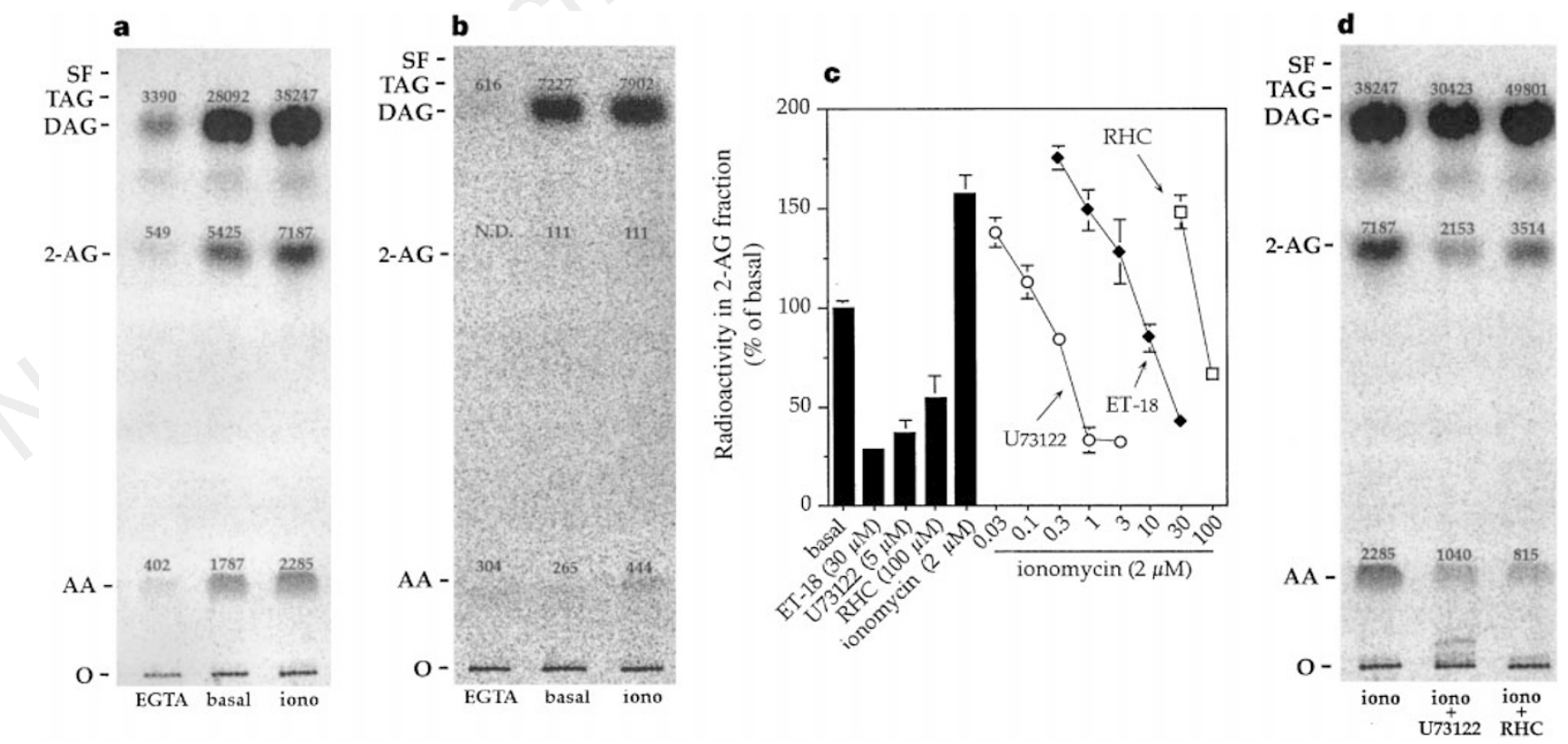

Figure $3 \mathrm{Ca}^{2+}$-dependence, cellular localization and role of PLC and DAG lipase activities in 2-AG formation. $\mathbf{a}$, $\mathrm{Ca}^{2+}$-dependent production of $\left[{ }^{14} \mathrm{C}\right] 2-\mathrm{AG}$ in cultured neurons labelled overnight with $\left[{ }^{14} \mathrm{C}\right]$ arachidonic acid (AA). Representative TLC analysis of samples from 10-min incubations with $1 \mathrm{mM}$ EGTA (EGTA), no additions (basal), or $2 \mu \mathrm{M}$ ionomycin (iono). The bars indicate the chromatographic mobilities of AA, 2-AG, diacylglycerol (DAG) and triacylglycerol (TAG); the numbers represent average radioactivity in each component (d.p.m. $\mathrm{mg}^{-1}$ protein, s.e.m. $\leq 10 \%, n=6$ ); O, origin; SF, solvent front. The effect of ionomycin on $\left[{ }^{14} \mathrm{C}\right] 2-\mathrm{AG}$ accumulation was time-dependent: $5 \mathrm{~min}, 104 \pm 3 \%$ of control; $10 \mathrm{~min}, 162 \pm 18 \% ; 20 \mathrm{~min}, 188 \pm 10 \%(n=4)$. Under all conditions, specific radioactivity in $\left[{ }^{14} \mathrm{C}\right] 2-\mathrm{AG}$ was $\sim 50 \mathrm{pCi}$ pmol ${ }^{-1}$. b. Effects of EGTA $(1 \mathrm{mM})$ and ionomycin $(2 \mu \mathrm{M})$ on $\left[{ }^{14} \mathrm{C}\right] 2-\mathrm{AG}$ production in cortical astrocytes. Representative TLC analysis and average radioactivities from 4 experiments (s.e.m. $\leq 20 \%$ ). $\left[{ }^{14} \mathrm{C}\right] \mathrm{AA}$ under basal conditions was increased significantly by the addition of ionomycin; $P<0.05 \%$ (unpaired Student's $t$-test); nd, not detectable. c, Effects of PLC inhibitors (U73122, ET-18) and DAG lipase inhibitor (RHC) 80267 on $\left[{ }^{14} \mathrm{C}\right] 2-\mathrm{AG}$ production in cortical neurons. The drugs were applied alone (bars) or in the presence of $2 \mu \mathrm{M}$ ionomycin (circles, U73122; diamonds, ET-18; squares, RHC 80267). Results are expressed as percentage of basal [ $\left.{ }^{14} \mathrm{C}\right] 2-\mathrm{AG}$ production (which was 5,425 \pm 149 d.p.m. $\mathrm{mg}^{-1}$ protein) and represent the mean \pm s.e.m. of 6 experiments. d, Effects of PLC and DAG lipase inhibitors on ionomycin-induced formation of $\left[{ }^{14} \mathrm{C}\right] \mathrm{DAG},\left[{ }^{14} \mathrm{C}\right] 2-\mathrm{AG}$ and $\left[{ }^{14} \mathrm{C}\right] \mathrm{AA}$ in neurons. Representative TLC analysis and average radioactivities from 6 experiments (s.e.m. $\left.\leq 10 \%\right)$. Concentrations of U73122 and RHC 80267 were $5 \mu \mathrm{M}$ and $100 \mu \mathrm{M}$, respectively. 
astrocytes may produce $2-\mathrm{AG}$, the $\mathrm{Ca}^{2+}$-dependent formation of this lipid may be less prominent in astrocytes than in neurons. 2-AG may be produced through three main biochemical routes. In intestine, 2-AG accumulates during the digestion of dietary triacylglycerols ${ }^{20}$. In other tissues, 2-AG formation may result from the cleavage of phospholipids in membranes (initiated by phospholipase C; PLC) ${ }^{21}$ or from the breakdown of triacylglycerols (initiated by neutral lipase) ${ }^{20}$. The PLC inhibitor U73122 is potent in preventing the accumulation of $\left[{ }^{14} \mathrm{C}\right] 2-\mathrm{AG}$ in neurons (Fig. $3 \mathrm{c}, \mathrm{d}$ ), with a median inhibitory concentration $\left(\mathrm{IC}_{50}\right)$ of $0.2 \mu \mathrm{M}$. To confirm these results and test which PLC isoenzyme(s) may be implicated, we used two additional PLC inhibitors: ET-18, which blocks phosphoinositide-specific PLC, and D-609, which blocks phosphatidylcholine-specific PLC. ET-18 prevented $\left[{ }^{14} \mathrm{C}\right] 2-\mathrm{AG}$ formation with an $\mathrm{IC}_{50}$ of $5 \mu \mathrm{M}$ (Fig. 3c), whereas D-609 was ineffective even when used at $100 \mu \mathrm{M}$ (ionomycin, $170 \pm 12 \%$ of basal; ionomycin plus D-609, $242 \pm 37 \%$ of basal, $n=6$ ).

The primary lipid product of PLC activity is diacylglycerol (DAG), which is then hydrolysed to $s n-2$ acylglycerol by DAG lipase activity $^{22}$. If $2-\mathrm{AG}$ production in neurons is initiated by PLC, 2-AG should accumulate in parallel with DAG. Accordingly, $\left[{ }^{14} \mathrm{C}\right] \mathrm{DAG}$ and $\left[{ }^{14} \mathrm{C}\right] 2$-AG levels increased by a similar extent when neurons were incubated in a medium containing $\mathrm{Ca}^{2+}$ (basal) or $\mathrm{Ca}^{2+}$ plus ionomycin (Fig. 3a). We obtained further evidence that DAG serves as a precursor for 2-AG using the DAG lipase inhibitor RHC 80267. At $100 \mu \mathrm{M}$, this drug reduced both $\left[{ }^{14} \mathrm{C}\right] 2-\mathrm{AG}$ formation (Fig. 3c, d) and $\left[{ }^{14} \mathrm{C}\right]$ DAG hydrolysis (Fig. 3d), whereas it had no effect on $\left[{ }^{3} \mathrm{H}\right]$ inositol phosphate accumulation (data not
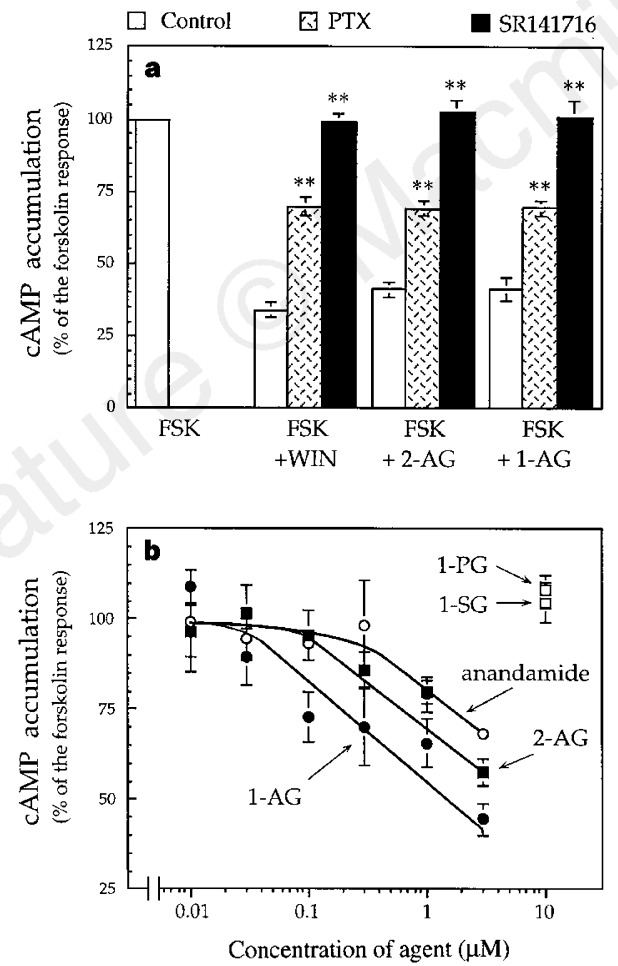

Figure 4 Activation of neuronal CB1 receptors by 2-AG. a, Inhibitory effects of WIN 55212-2 (WIN, $3 \mu \mathrm{M}), 2-A G(10 \mu \mathrm{M})$ or $1(3)-A G(10 \mu \mathrm{M})$ on forskolin-stimulated CAMP accumulation in rat cortical neurons (white bars). These effects were prevented by the CB1 receptor antagonist SR-141716 $(1 \mu \mathrm{M})$ (black bars) or by pertussis toxin (PTX; $1 \mu \mathrm{g} \mathrm{ml}^{-1}$ ) for $18-20 \mathrm{~h}$ (stippled bars). ${ }^{* *}, P<0.01$ (ANOVA followed by Dunnett's test). b, Concentration-dependent inhibition of CAMP accumulation by 2-AG, 1(3)-AG and anandamide, and lack of effect of 1(3)palmitylglycerol (1-PG) and 1(3)-stearylglycerol (1-SG). cAMP levels were measured in neurons after 10-min incubations in the presence of forskolin ( $3 \mu \mathrm{M})$ and 3-isobutyl-1-methylxanthine $(1 \mathrm{mM})$, using a commercial radioimmunoassay kit (Amersham, Arlington, IL). shown). These experiments suggest that 2-AG formation is mediated by PLC and DAG lipase activities. We cannot exclude, however, that other lipases such as $\mathrm{PLA}_{1}$ or triacylglycerol lipase may also be involved.

We investigated next the functional consequences of 2-AG binding to $\mathrm{CB} 1$ cannabinoid receptors. Cortical neurons in culture express CB1 receptors that are negatively coupled to adenylyl cyclase activity through a $\mathrm{G}_{\mathrm{i}} / \mathrm{G}_{\mathrm{o}}$ protein ${ }^{23}$. Accordingly, the $\mathrm{CB} 1$ receptor agonist WIN-55212-2 (3 $\mu \mathrm{M})$ inhibited forskolin-induced cAMP accumulation, an effect that was reverted by the CB1 antagonist SR$141716(1 \mu \mathrm{M})$ or by pertussis toxin (Fig. $4 \mathrm{a})$. 2-AG $(10 \mu \mathrm{M})$ elicited a quantitatively similar inhibition which was also sensitive to SR-141716 and pertussis toxin (Fig. 4a). This effect occurred with
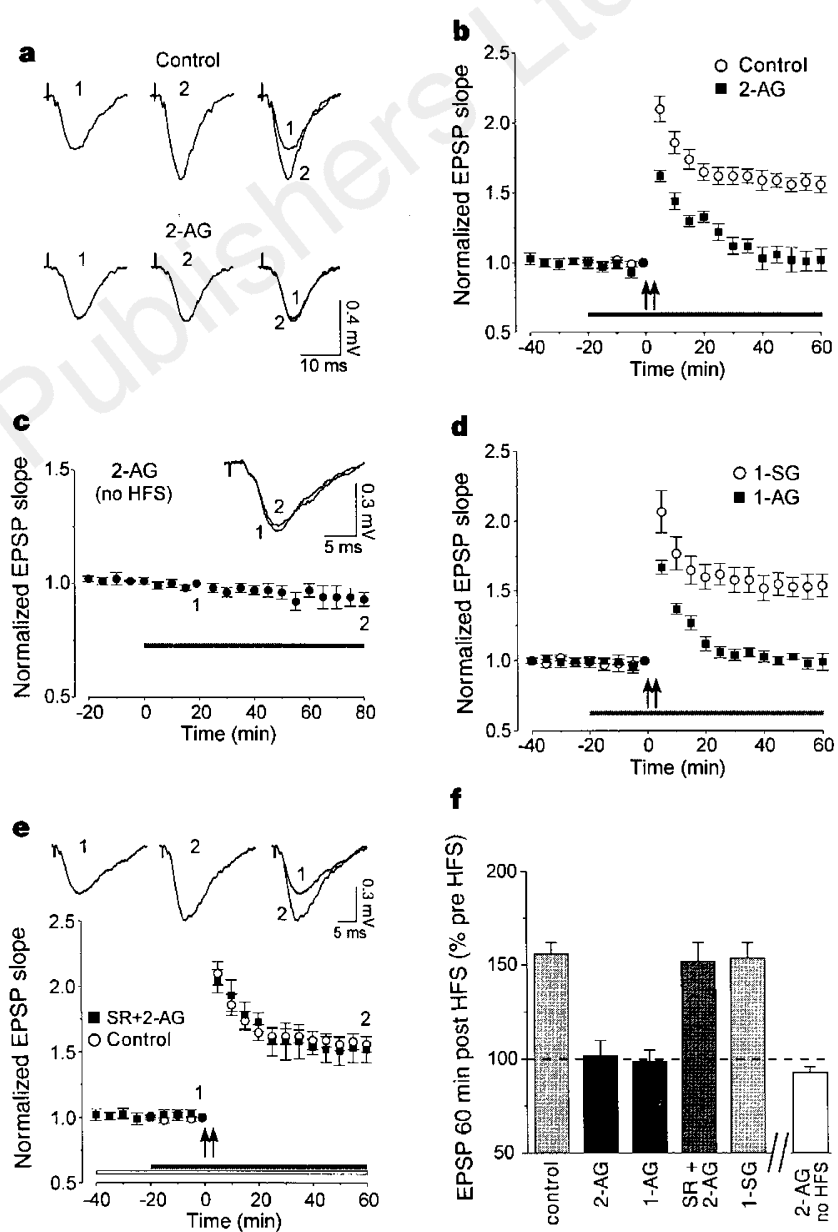

Figure 5 2-AG prevents the induction of LTP. a, Sample traces showing CA1 field excitatory postsynaptic potentials (EPSPS) (1) before and (2) $60 \mathrm{~min}$ after HFS of the Schaffer collaterals. The upper traces show control potentiation of EPSP slope and amplitude 60 min after HFS. The lower traces show inhibition of this potentiation by 2-AG $(20 \mu \mathrm{M})$. b. Time course of field EPSP slope (normalized to pre-tetanus). 2-AG (20 $\mu \mathrm{M}$, filled squares; $n=6)$ inhibited LTP (empty circles; $n=7$ ). Drug application is denoted by the solid bars. HFS was delivered at the time shown by the double arrow. Results in this and all graphs represent mean \pm s.e.m. c, 2 -AG ( $20 \mu \mathrm{M} ; n=4)$ had no significant effect on EPSP in the absence of HFS. The sample traces depict EPSP obtained at times indicated by the numbers. d, 1(3)-Stearylglycerol ( $20 \mu \mathrm{M}$, empty circles; $n=3)$ did not affect LTP, whereas 1(3)-AG (20 $\mu \mathrm{M}$, filled squares; $n=5)$ completely blocked LTP. e, LTP inhibition by 2-AG was prevented by prior application (white bar) of SR-141716 (SR, $2 \mu \mathrm{M}$, filled squares, $n=3$ ) and LTP was similar to control (empty circles). The recordings depict EPSPs obtained in a slice treated with SR-141716 and 2-AG. f, Effects of pharmacological agents on EPSP potentiation 60 min after HFS. Values are expressed as percentage of the EPSP before HFS or an equivalent time for the white bar, which represents the EPSP slope in non-tetanized slices after 80-min exposure to 2-AG (20 $\mu \mathrm{M})$. 
a potency $\left(\mathrm{IC}_{50}=0.8 \mu \mathrm{M}\right.$, Fig. $\left.3 \mathrm{~b}\right)$ consistent with the affinity of 2-AG for CB1 receptors $\left(K_{\mathrm{i}}=0.7-2.4 \mu \mathrm{M}\right)^{4,17}$ and comparable to the potency of anandamide ( $\mathrm{IC}_{50}=1.2 \mu \mathrm{M}$, Fig. $\left.4 \mathrm{~b}\right) .1$ (3)-AG also decreased cAMP accumulation, whereas 1(3)-palmitylglycerol and 1(3)-stearylglycerol had no effect (Fig. 4b). These results indicate that 2-AG activates neuronal $\mathrm{CB} 1$ receptors as a full agonist and with a potency similar to that of anandamide.

CB1 agonists inhibit hippocampal long-term potentiation (LTP $)^{24,25}$, a model for learning and memory, and impair shortterm memory tasks that are associated with the firing of hippocampal cells ${ }^{26,27}$. We therefore examined whether 2-AG affects LTP expression. HFS of the Schaffer collaterals caused a sustained increase in the slope of the field excitatory postsynaptic potentials (EPSP) recorded in CA1 stratum radiatum: the EPSP slope measured 60 min after HFS was $156 \pm 6 \%$ of basal values measured before HFS (Fig. 5a, b). LTP was completely suppressed when 2-AG $(20 \mu \mathrm{M})$ was administered before HFS (102 $\pm 8 \%$ of basal; Fig. 5a, b). By contrast, 2-AG had little or no effect on EPSP when administered to non-tetanized slices (Fig. 5c, f). Moreover, 2-AG had no effect on established LTP $(160 \pm 7 \%$ of basal, $n=4)$. The blockade of LTP by 2-AG probably resulted from the activation of CB1 receptors, because: (1) the active isomer 1(3)-AG, but not 1(3)stearylglycerol, prevented LTP induction (Fig. 5d, f); and (2) 2AG had no effect on LTP when applied together with the CB1 antagonist SR-141716 $(2 \mu \mathrm{M})(152 \pm 10 \%$ of basal; Fig. 5e, f $)$. These results suggest that 2-AG acting at $\mathrm{CB} 1$ receptors inhibits LTP induction without affecting basal synaptic transmission.

In conclusion, we have shown that neural activity and $\mathrm{Ca}^{2+}$ entry may evoke the formation of 2-AG which may, in turn, activate CB1 receptors in neurons and modulate the induction of LTP at CA3/ CA1 synapses. Our experiments suggest therefore that 2-AG, like anandamide, may serve an endogenous cannabinoid role. However, 2-AG appears to differ from anandamide in at least two ways. First, the formation of 2-AG may be initiated by PLC activity, whereas that of anandamide may be catalysed by PLD activity ${ }^{5,11,28}$. Second, 2-AG and anandamide may be produced under distinct physiological conditions or in distinct brain regions. Thus, despite their common ability to activate cannabinoid receptors, the physiopathological implications of these signalling molecules may be different. Such demarcation should be instrumental in identifying pharmacological agents that selectively interfere with discrete components of the endogenous cannabinoid system.

\section{Methods}

Lipid analyses. The methods used for rapid brain freezing, methanol/ chloroform extraction of the lipids, open-bed chromatography and normal phase high-performance liquid chromatography (HPLC) have been described previously ${ }^{14}$. TLC analyses were carried out on silica gel G plates, eluted with a solvent system consisting of the organic phase of ethyl acetate/methanol/water/ ammonia $(20: 1: 10: 1, \mathrm{v} / \mathrm{v})$. Synthetic standards were visualized by phosphomolybdic acid staining, and radioactive lipids were localized by autoradiography using a Phosphor-Imager 445 SI apparatus (Molecular Dynamics, Sunnyvale, CA). Radioactivity in TLC fractions was determined by liquid scintillation counting. For GC/MS analyses of acylglycerols as TMS derivatives $^{14}$, we added 1(3)-eicosanoylglycerol (1.2 mol, Nu-Check Prep, Elysian, MN) to tissue or cell culture homogenates, as internal standard. The TMS derivative of 1(3)-eicosanoylglycerol was eluted from the GC at a retention time of $20 \mathrm{~min}$, and its electron-impact mass spectrum displayed a series of informative ions which included $m / z 515$ [M-15] $^{+}$(loss of a methyl radical) and $m / z 427[\mathrm{M}-103]^{+}\left(\right.$loss of $\left[\mathrm{TMSOCH}_{2}\right]^{+}$). The ion at $m / z 427$ was used in quantitative SIM analyses to calculate recoveries. After correction for recoveries, brain 2-AG was quantified by comparison with calibration curves constructed using synthetic 2-AG. The GC/MS isotope dilution method used to quantify anandamide as TMS derivative will be described in detail elsewhere (A. Giuffrida, R. Kuczenski and D.P., manuscript in preparation).

Cell cultures, radioactive labelling and incubations. Primary cultures of cortical neurons (5-7 days in vitro) or astrocytes (6-8 weeks in vitro) were prepared as described previously ${ }^{6,29}$. Cells maintained in 6-mm culture dishes were incubated for $18-20 \mathrm{~h}$ with $\left[{ }^{14} \mathrm{C}\right]$ AA (Amersham, $54 \mathrm{mCi} \mathrm{mmol}^{-1}$; $0.05 \mu \mathrm{Ci} \mathrm{ml}^{-1}$ with $0.01 \% \mathrm{BSA}$ ). The cells were rinsed twice for $10 \mathrm{~min}$ with a HEPES-bicarbonate buffer composed of (in $\mathrm{mM}$ ): $\mathrm{NaCl} 120 ; \mathrm{KCl}$ 5.0; $\mathrm{CaCl}_{2} 2.0$; $\mathrm{MgSO}_{4}$ 1.0; $\mathrm{NaH}_{2} \mathrm{PO}_{4}$ 1.0; glucose 10; $\mathrm{NaHCO}_{3} 5.0$ and HEPES 20 (pH 7.4, $37^{\circ} \mathrm{C}$ ). The cells were then incubated for $10 \mathrm{~min}$ in the same buffer containing drugs at the indicated concentrations. For lipid analyses, incubations were stopped by adding $2 \mathrm{ml}$ of ice-cold methanol followed by chloroform extraction. Hippocampal slice stimulations and LTP experiments. Slices of rat hippocampus were prepared as described previously $y^{30}$. Briefly, transverse slices $\left(350-400 \mu \mathrm{m}\right.$ thick) were cut and superfused $\left(2-3 \mathrm{ml} \mathrm{min}^{-1}\right)$ with warm, gassed $\left(31^{\circ} \mathrm{C}, 95 \% \mathrm{O}_{2}, 5 \% \mathrm{CO}_{2}\right)$ artificial cerebrospinal fluid (ACSF) of the following composition (mM): $\mathrm{NaCl} 130 ; \mathrm{KCl} 3.5 ; \mathrm{NaH}_{2} \mathrm{PO}_{4} 1.25 ; \mathrm{MgSO}_{4}$ 1.5; $\mathrm{CaCl}_{2} 2.0 ; \mathrm{NaHCO}_{3} 24$; glucose 10. We stimulated the Schaffer collaterals using a concentric bipolar tungsten electrode $(0.1 \mathrm{~ms}$ pulses $)$. To measure stimulation-dependent 2-AG production, the HFS consisted of 2 trains $(100 \mathrm{~Hz})$ of $1 \mathrm{~s}$ each applied $20 \mathrm{~s}$ apart at an intensity that evoked maximal field EPSPs (as determined in separate experiments); 4 hippocampal slices were placed in the chamber and consecutively stimulated. At the end of the stimulation period ( $2 \mathrm{~min}$ ), we immersed the slices in $2 \mathrm{ml}$ of ice-cold methanol containing 1(3)-eicosanoylglycerol $(1.2 \mathrm{nmol})$ and $\left[{ }^{2} \mathrm{H}\right]_{4}$ anandamide ( $1.2 \mathrm{nmol}$ as internal standards). The slices were homogenized and subjected to lipid analysis (see above). For LTP experiments, we recorded EPSPs with an extracellular $3 \mathrm{M} \mathrm{NaCl}$-filled glass electrode (resistance $1-3 \mathrm{~m} \Omega$ ) placed in CA1 stratum radiatum, while stimulating the Schaffer collaterals at an intensity sufficient to evoke a $40 \%$ maximal response. The same intensity was kept for the HFS, which consisted of 2 trains $(100 \mathrm{~Hz})$ of $1 \mathrm{~s}$ each, applied $20 \mathrm{~s}$ apart. Drugs were added to the ACSF from stock solutions in dimethyl sulphoxide. The final concentration of dimethyl sulphoxide was $0.1 \%$. Preliminary GC/MS analyses showed that $30 \%$ of exogenously added 2-AG (Deva Biotech, Harboro, PA) was adsorbed to the superfusion apparatus. Therefore, to obtain a final concentration of $20 \mu \mathrm{M}$, we added $30 \mu \mathrm{moll}^{-1} 2$-AG to the ACSF.

Received 10 April; accepted 18 June 1997.

1. Herkenham, M. et al. Cannabinoid receptor localization in brain. Proc. Natl Acad. Sci. USA 87, 1932 1936 (1990)

2. Howlett, A. C. Pharmacology of cannabinoid receptors. Annu. Rev. Pharmacol. Toxicol. 35, 607-634 (1995).

3. Devane, W. A. et al. Isolation and structure of a brain constituent that binds to the cannabinoid receptor. Science 258, 1946-1949 (1992).

4. Mechoulam, R. et al. Identification of an endogenous 2-monoglyceride, present in canine gut, that binds to cannabinoid receptors. Biochem. Pharmacol. 50, 83-90 (1995).

5. Di Marzo, V. et al. Formation and inactivation of endogenous cannabinoid anandamide in central neurons. Nature 372, 686-691 (1994).

6. Cadas, H., Gaillet, S., Beltramo, M., Venance, L. \& Piomelli, D. Biosynthesis of an endogenous cannabinoid precursor in neurons and its control by calcium and cAMP. J. Neurosci. 16, 3934-3942 (1996).

7. Beltramo, M. et al. Functional role of high-affinity anandamide transport, as revealed by selective inhibition. Science (in the press).

8. Desarnaud, F., Cadas, H. \& Piomelli, D. Anandamide amidohydrolase activity in rat brain microsomes. J. Biol. Chem. 270, 6030-6035 (1995).

9. Ueda, N., Kurahashi, Y., Yamamoto, S. \& Tokunaga, T. Partial purification and characterization of the porcine brain enzyme hydrolyzing and synthesizing anandamide. J. Biol. Chem. 270, 23823-23827 (1995)

10. Cravatt, B. F. et al. Molecular characterization of an enzyme that degrades neuromodulatory fatty-acid amides. Nature 384, 83-87 (1996).

11. Sugiura, T. et al. Transacylase-mediated and phosphodiesterase-mediated synthesis of $\mathrm{N}$-arachidonoylethanolamine, an endogenous cannabinoid-receptor ligand, in rat brain microsomes. Eur. J. Biochem. 240, 53-62 (1996).

12. Schmid, P. C. et al. Corrigendum to: Occurrence and postmortem generation of anandamide and other long-chain $\mathrm{N}$-acylethanolamines in mammalian brain. FEBS Lett. 385, 125 (1996).

13. Felder, C. C. et al. Isolation and measurement of the endogenous cannabinoid receptor agonist, anandamide, in brain and peripheral tissues of human and rat. FEBS Lett. 393, 231-235 (1996).

14. Cadas, H., di Tomaso, E. \& Piomelli, D. Occurrence and biosynthesis of endogenous cannabinoid precursor, $\mathrm{N}$-arachidonoyl phosphatidylethanolamine, in rat brain. J. Neurosci. 17, 1226-1242 (1997).

15. Smith, P. B. et al. The pharmacological activity of anandamide, a putative endogenous cannabinoid, in mouse. J. Pharmacol. Exp. Ther. 270, 219-227 (1994).

16. Evans, D. M., Lake, J. T., Johnson, M. R. \& Howlett, A. C. Endogenous cannabinoid receptor binding activity released from rat brain slices by depolarization. J. Pharmacol. Exp. Ther. 268, 1271-1277 (1994).

17. Sugiura, T. et al. 2-arachidonoylglycerol: a possible endogenous cannabinoid receptor ligand in brain. Biochem. Biophys. Res. Commun. 215, 89-97 (1995).

18. Bazan, N. G. Effects of ischemia and electroconvulsive shock on fatty acid pool in the brain. Biochim. Biophys. Acta. 218, 1-10 (1970).

19. Weiss, S. et al. Synaptogenesis of cultured striatal neurons in serum-free medium: a morphological and biochemical study. Proc. Natl Acad. Sci. USA 83, 2238-2242 (1986).

20. Brindley, D. N. in Biochemistry of Lipids and Membranes (eds Vance, D. E. \& Vance, J. E.) 213-241 (Benjamin/Cummings, Menlo Park, 1985).

21. Prescott, S. M. \& Majerus, P. W. Characterization of 1,2-diacylglycerol hydrolysis in human platelets. J. Biol. Chem. 258, 764-769 (1983). 